\title{
The Research of M\&A Performance of Private Listing Corporation Based on Different M\&A Incentives
}

\author{
Cui Zhe, Xie Jia \\ School of Business, Nantong University, Nantong, China
}

Email address:

7790@vip.163.com (Cui Zhe)

\section{To cite this article:}

Cui Zhe, Xie Jia. The Research of M\&A Performance of Private Listing Corporation Based on Different M\&A Incentives. International Journal of Economics, Finance and Management Sciences. Vol. 4, No. 5, 2016, pp. 241-249. doi: 10.11648/j.ijefm.20160405.12

Received: May 12, 2016; Accepted: May 27, 2016; Published: August 17, 2016

\begin{abstract}
The paper researches the influence on M\&A performance from the perspective of the motive of enterprises mergers and acquisitions. The return on assets was selected to be the indicator to measure enterprises' performance after mergers and acquisitions, and it functioned as the dependent variable. The paper choose the representative company's agent motivation and the motivation of the equity concentration, the ratio of stated-owned shares, the ratio of managerial ownership, the ratio of circulation shares, Tobin's $Q$ value and return on equity as independent variables to build the model, and analyzes its impact. The empirical results shows: the ownership concentration and the ratio of the top executives have a positive correlation with the performance of the enterprises, but not significant; The ratio of state-owned shares and the ratio of circulation shares have a negative correlation with the performance of M\&A; Tobin's $Q$ value and return on equity have a significant positive correlation with the performance of the enterprises after M\&A. The research indicates: the M\&A behavior based on different motivations positively has impact on the performance of enterprises after M\&A. The research and analysis of the M\&A motive is beneficial to better regulate and supervise the M\&A behavior and promote the development of enterprises.
\end{abstract}

Keywords: Private Listed Companies, Mergers and Acquisitions Incentive, Mergers and Acquisitions Performance

\section{Introduction}

Enterprises M\&A is a decision-making behavior of enterprise production and management, which is an important way to promote industrial structure optimization and upgrading. It can change the original production and operation mode and bring about scale economies effect for production and management, so as to enhance the enterprise's market competitiveness.

Enterprise M\&A originated in the late 19th century and the beginning of the 20th century. So far, there have been a total of five waves of M\&A internationally and the characteristics of the show are also different. As an effective way to promote the long-term development of enterprises, improve the comprehensive competitiveness of enterprises and rational allocation of resources, more and more enterprises seek development through M\&A.

China's enterprises M\&A sprang up in 1980s. Since China joined WTO, the economic activities become more and more globalized, and the domestic and international competitions are more and more fierce. The development of enterprises can not be satisfied with the use of the existing conditions and resources. For better development, the enterprise must rely on and integrate more resources, which make China's M\&A activities frequently occur. As an important part of China's economic development, i.e. private enterprises, are also playing more and more important role in M\&A, enhancing the strength of enterprises and promoting the development of enterprises by taking $\mathrm{M} \& \mathrm{~A}$ as an opportunity.

Since the first private company listed in 1992, the number of private enterprise and listing corporations are increasing with each passing day. As of March 2014, China's private enterprises in the listing corporation accounted for more than $50 \%$. Specifically speaking, private enterprises accounted for $30.06 \%$ among the main board of listing corporations in China. Among GEM listing corporations, private enterprises accounted for $95.92 \%$. Among small and medium enterprise board listing corporations, private enterprises accounted for $76.18 \%{ }^{1}$. It can be seen that the private listing corporations in

1 The data comes from the China Securities Regulatory Commission. 
the economic system of our country occupy an important position, so that the healthy growth and development of private enterprises can promote the economics' development of our country.

However, the cases of business failures and the company's performance reduction after M\&A should also make us alert, which is appearing in the market continuously. Although from optimizing the allocation of resources and promoting the development of enterprises to implement mergers and acquisitions, the results are often not as good as expected, which is not unrelated to the original merger and acquisition of enterprises. M\&A incentive of enterprises is an important factor to influence M\&A performance. Therefore, the paper selects appropriate indicators to analyze the causes which influence M\&A performance and puts forward some suggestions based on the analysis of the data of private listed companies.

\section{Theoretical Basis of M\&A Incentive}

M\&A referring to the behavior of mergers and acquisitions between enterprises, that is, the legal body of enterprise obtains other legal person's property rights in a certain manner on the basis of equality, voluntary, and equivalent compensation. And it is the main form of capital operation and management. According to different standards, we can divide M\&A into different types. From the industrial point of view, M\&A can be divided into horizontal M\&A, vertical and mixed M\&A. In accordance with the way of payment, M\&A can be divided into cash M\&A, stock M\&A and hybrid payment means M\&A. In accordance with the acquisition, $M \& A$ can be divided into hostile $M \& A$ and bona fide M\&A.

\subsection{Theory of Western Economics on $M \& A$ Incentive}

The rise of M\&A behavior and the complexity behind it have economists committed to exploring and studying M\&A behavior for many years. After the research and development, the western economists tend to explain the reasons for the enterprise mergers and acquisitions from the following aspects.

\subsubsection{Mergers and Acquisitions Based on the Company's Operating Incentives}

New classical economics believe that the enterprise production and management aim to realize the maximization of enterprise profit and the minimization of the cost. In other words, if production reaches certain level, enterprises always want to invest as less as possible to profit as many as possible. The scale economies effect of the new classical economics shows that, in a certain period, the production cost will be reduced gradually with the expansion of production scale. It reasonably explains the behavior of the enterprise's horizontal M\&A. Under the condition of the scale economy effect, the enterprise will have the motivation to expand the scale of the enterprise. The transaction cost theory, which is proposed by Kos in 1937, is the basis of the theory of modern property rights. He thought that the enterprise is a substitute of market mechanism and enterprises and the market are two kinds of alternative method $^{2}$ for resource allocation. The existence of opportunism and other uncertain factors will increase the cost of market transactions, but the cost of the internal departments of the enterprise is lower than the market transaction costs. As long as the transaction costs in the market are higher than the cost of the enterprise internalization, the enterprise can reduce the cost and the risk by integrating the resources.

Later, Williamson made some explanation based on this and put forward the "asset specific" theory. He thought that asset specificity is an important factor to determine the level of transaction costs, which means the extent of carrying out production in different use in the circumstance of not damaging the value of assets survival. If the value of this asset for a particular use is greater than the value created by other ways, this kind of asset will have assets specificity. When the asset specificity is high, the internal organization of the enterprise is in a dominant position and it is suitable for the trade of internal. When the asset specificity is low and the transaction cost is small, it is more suitable for trading in the market [3]. According to the above theory, we know that when a transaction's asset specificity and the cost of the market are high, the enterprise has the incentive to integrate various resources to carry out internal production, which generates vertical M\&A.

\subsubsection{M\&A Theory Based on Company's Decision-Making Incentives}

Under modern enterprise system, the ownership of enterprise separates from the control right and the owner of the company may not be the decision maker of the operation. And the objective function between principals and agents is not usually the same. For example, the shareholders of the company pursue the maximization of the investment income and the value of the company while the manager mostly go after the maximization of their own rights such as higher salary and greater operational control right. However, due to the existence of information asymmetry, the company's agent who masters more comprehensive understanding of the company's information know more information than the client, so that the client is difficult to distinguish the behavior incentive of the agent, which will cause the "agency problem".

Jensen (1986) proposed the hypothesis of "free cash flow" in M\&A by researching. Free cash flow refers to the residual cash after a company paying its net present value for the project. When enterprises have more free cash flow, shareholders expect the manager to invest spare cash flow or release it in the form of dividends according to the principle of realizing the company's value maximization ${ }^{3}$. But it will reduce the management control of the managers, thus producing the conflicts of interests between principals and agents.

\footnotetext{
2 Kos (1937) transaction cost theory

3 Ensen (1986) on the "free cash flow" hypothesis of M\&A
} 


\subsection{The Relationship Between $M \& A$ Motives and $M \& A$ Performance}

M\&A motive is the starting point and standing point of enterprise's M\&A behavior, and the motivation of stakeholders in the enterprise M\&A activities. The motivations of M\&A mainly include synergistic effect motives, free cash flow hypothesis, strategic restructuring motives, agency motives, diversification motives, arrogance motives and so on. Berkovitch (1993) divided the motivations of enterprise M\&A into three main kinds: synergistic effect motive, arrogance motive, and agency motive. Other M\&A motives originate from these three kinds of motives.

\subsubsection{Synergistic Motivation and $M \& A$ Performance}

The synergy effect motivation means that both the targets and the buyers' M\&A behaviors aim at achieving the maximization of shareholder wealth and enhancing the company's value. M\&A will only be conducted under the premise of increasing the income of both shareholders and improving the company's performance. The synergy effects improve the companies' performance mainly through the following ways:

Firstly, the operation synergy effect of M\&A can reduce the operating cost and improve the enterprise's performance. M\&A behavior reduced the enterprise management cost and the operating costs, improving the value of the enterprise. By the scale economy, we know that under a certain market environment and technical conditions, the enterprise's expanding of the scale of production can reduce the cost of unit product and improve productive efficiency. Not only do enterprises take full advantages of the existing market, production condition and sales channels of the original enterprise through the expansion realized by M\&A, but also reduce and avoid the cost and uncertainty of the expansion of their own investment. In addition, the operating synergies also play a unique value in the vertical M\&A events. Enterprises with vertical collaborative relationships can integrated upstream and downstream resources and improve efficiency, reducing transaction costs. The vertical M\&A of enterprises makes every part of the production process incorporated into the same enterprise, reducing transaction costs and improving the production efficiency of enterprises, thus achieving business synergies.

Secondly, M\&A can improve the company's performance through the realization of financial synergy effect. The financial synergy effect refers to the target enterprises and acquiring enterprises being integrated, coordinating finance conditions and improving financial capacity of the enterprise through mergers and acquisitions, thereby increasing the value of the enterprise. When an enterprise has abundant non-distributed free cash flow over a long time, the distribution of dividends will increase the individual income tax paid by shareholders. However, the act of M\&A can not only increase the personal property of the shareholders, but also reduce the payment of their personal income tax. Besides, M\&A have a unique advantage in the use of financing and capital. The increase of the amount of capital, which reduces the risk of creditors, can get more financing opportunities and more efficient scheduling of funds, thus improving the utilization rate of cash.

Thirdly, M\&A can realize the management synergy effect and improve the performance of the acquiring company. The difference between the superior enterprise and the inferior position in the management efficiency of the enterprise motivate the superior enterprise to implement M\&A in order to obtain more available resources. When mergering the enterprises in the inferior position, the target enterprises' efficiency will be improved after M\&A behavior, consequently achieving the effect of ' $1+1>2$ '.

\subsubsection{Agency Motivation and $M \& A$ Performance}

Under the modern enterprise system, the ownership separates from the management right and the company's owner is not the operator of the company. Professional managers have more management rights. Because of the separation of these two powers, principal-agent problems inevitably came out. Management layer may not see company's maximum interests as ultimate goal. The research found that the professional managers are in the hope of expanding the size of the company and want to achieve the maximization of personal interests. In this way, M\&A has become the most convenient and effective means to achieve the intention. A large number of domestic and foreign research data also shows that M\&A behaviors based on the motives of the agency can not earn profit for acquiring enterprises. M\&A behaviors of agency motives result in the loss of shareholders from the following aspects:

First of all, the agent's motivation takes the manager's own needs as the primary consideration, tending to ignore or even never consider the interests of shareholders. Managers will be eager to seek mergers and acquisitions for their own work, expanding the scale, even if the company does not have the scale of expansion at that time. Second, the managers buck for business control by hook or by crook. Under the mode of separation of two powers, the position of corporate executives is more than a job but a symbol of power, which will give them a sense of satisfaction, and the behavior of equity mergers and acquisitions will eventually give managers more power. The lack of effective supervision of power operation will lead to more serious problem of agency. Third, managers are longing to get more and more reward. Manager's reward is related with the performance, if M\&A behavior is beneficial to the individual interests of the manager, the manager will sacrifice the interests of the shareholders to merger and invest.

\subsubsection{Arrogance Motivation and $M \& A$ Performance}

Arrogance motivation is a motive that managers are too confident in their own abilities and judgment. Decisions mainly made by the individual and often result in wrong judgment, and finally cause the failure of mergers and acquisitions. Under normal circumstances, the enterprise evaluates and judges the target enterprise according to stock price information and so on before the merger. But the management with arrogance thinks that stock price information can not fully describe the value of the enterprise, consequently the cost in the acquisition process is too high, thus influencing the profits in M\&A action. 


\section{Research Assumption}

\subsection{Concentration Ratio of Shares}

Concentration ratio of shares is an important index to consider the status of the distribution of shares of the company, which refers to the percentage of shares hold by the largest shareholder in total volume. As the No. 1 major shareholder of the company, when proportion of shareholding is large, means the shareholder has a greater power, thus effectively controlling and supervising the management, thereby reducing the behaviors of enterprises' managers implementing M\&A based on the agency motives. The empirical study conducted by Feng Gengfu and Wu Linjiang (2001) also shows, when shareholding ratio of the largest shareholder of the company is greater, the company's performance is better after $M \& A^{4}$. Therefore, the paper puts forward Assumption one:

M\&A performance has a positive correlation with concentration ratio of shares.

\subsection{The Ratio of State-Owned Shares}

Although enterprises have adopted a series of measures to reform in recent years, China has always maintained the characteristics of nature of enterprise state owned shares. These reforms did not fundamentally solve the ownership problem caused by the high proportion of state-owned shares. State holding companies are more inclined to make the acquisition of the agents' motives. As an abstract subject, the country's power has to be exercised by agents. And the existence of the principal-agent relationship between the state and agents makes the agents can not receive the full supervision; therefore agents are likely to take more consideration of their own interests to conduct M\&A. Under this kind of merger motive, M\&A impulse is not beneficial to the development of enterprises. Once the ratio of state-owned shares is too high, the management will get access to the company's actual control. So the higher ratio of state-owned shares is, the more obvious agency-motivated actions will be in the process of M\&A. Therefore, the paper puts forward Assumption two:

The performance of M\&A has a negative correlation with the ratio of state-owned shares.

\subsection{The Ratio of Managerial Ownership}

Nowadays, China's more and more enterprises' ownership separates from control power. These two kinds of powers separate, so the goal that management and shareholders seeking is not consistent, that is, executives aim to maximize their own benefits, while the shareholders pursue investment income and the maximization of enterprise value. But the existence of information asymmetry makes it difficult for shareholders to fully monitor the operation process of every enterprise. Therefore, the controlling of equity incentives can make the interests of management layer and shareholders tend to be consistent, so that the managers can operate and manage the business due to shareholders' willingness. Therefore, the paper

4 Ensen (1986) on the "free cash flow" hypothesis of M\&A puts forward Assumption three:

The performance of M\&A has a positive correlation with the ratio of managerial ownership.

\subsection{The Ratio of Circulating Shares}

The ratio of circulating shares is the proportion that shares in the market accounting for in the total share capital of the enterprise. In the capitalist market, the company raised funds through the issuance of shares. Stocks flow freely, and small and medium shareholders will monitor company's decisions to protect their own interests. When institutional investors own the shares of the enterprise, they rarely give in to the decision of the management of the enterprise. If the decision is to damage the interests of the enterprise, the opposition of the institutional investors is stronger. Therefore, the paper puts forward Assumption four:

The performance of M\&A is positively related to the ratio of circulating shares.

\subsection{Tobin's $Q$ Value}

Tobin's $Q$ value is an important index to measure the value of assets, which means the specific value between market value of assets and the replacement value. The performance of the dominant M\&A behavior is relatively poor, which leads to a greater incentive to make M\&A behavior. Therefore, the paper puts forward Assumption five:

Enterprises' M\&A performance is positively related to Tobin's Q value.

\subsection{Return on Equity}

The return on equity is the specific value between net profit and average stockholder's rights and interests (average equity). Before M\&A behavior, the rate of return on equity of the acquiring company is an important factor that reflects whether the M\&A incentive is good. The higher the return on equity is, the more possible M\&A events are set up in a cooperative motive $^{5}$. In this paper, we use the return on equity (ROE) as an explanatory variable to measure shareholder's motivation. Therefore, the paper puts forward Assumption six:

Enterprises' M\&A performance is positively related to the return on net asset.

\section{Research Design}

\subsection{Sample Selection and Data Sources}

This article select the listed company as the buyer in M\&A incident as the object to study and analyze, selecting valid samples and data from the CSMAR database of Tai'an, the sample selection adopts the following criteria:

- In 2011-2013 A shares of listing corporation, select the enterprise which filters and adopts share acquisition, absorption merger and assets acquisition in reorganize forms as research object from the major restructuring

5 Ensen (1986) on the "free cash flow" hypothesis of M\&A 
event. Exclude other type event of M\&A and reorganization.

- Exclude enterprises with incomplete data in the inspection period.

- In 2011 - 2013, the Sample Firms conducted more than a merger event. Take the first acquisition event as the research object.

- M\&A assets of the M\&A company up to the target enterprises' $50 \%$, less than $50 \%$ of the sample shall be exclude.

Finally we get $172 \mathrm{M} \& \mathrm{~A}$ events as a valid sample. Later,
SPSS 19.0 was used to analyze the data.

\subsection{Variable Design}

\subsubsection{Explained Variable}

This paper mainly studies the influence of private enterprise's M\&A performance, explores the factors that M\&A incentive makes difference to the performance of M\&A and selects the return on assets as an important indicator to measure the performance of the enterprise as an explained variable.

\subsubsection{Explanatory Variable}

Table 1. The interpretation of explanatory variables.

\begin{tabular}{|c|c|c|c|}
\hline & Variables description & Abbreviation & Calculation method \\
\hline \multirow[t]{3}{*}{ Explained variable } & Return on assets & ROA & Net profit/Average balance of total assets \\
\hline & Concentration ratio of shares & CRL & $\begin{array}{l}\text { The first shareholder number of shares in the year before M\&A/Number of } \\
\text { equity }\end{array}$ \\
\hline & The ratio of stated-owned shares & CRG & $\begin{array}{l}\text { The number of state-owned shares in the year before M\&A/The total number of } \\
\text { equity }\end{array}$ \\
\hline \multirow[t]{4}{*}{$\begin{array}{l}\text { Explanatory } \\
\text { variables }\end{array}$} & The ratio of managerial ownership & CRF & $\begin{array}{l}\text { The number of shares of enterprise executives in the year before M\&A/The } \\
\text { total number of equity }\end{array}$ \\
\hline & The ratio of circulation shares & CRM & $\begin{array}{l}\text { The number of enterprise circulation shares in the year before M\&A/The total } \\
\text { number of equity }\end{array}$ \\
\hline & Tobin's Q & TBQ & The market value of enterprise assets in the year before $\mathrm{M} \& \mathrm{~A} / \mathrm{The}$ book value \\
\hline & Return on equity & ROE & The enterprise net income in the year before M\&A/Shareholders' equity value \\
\hline
\end{tabular}

\subsection{Regression Model}

By means of a series of definitions of the variables, we show that the performance of M\&A is influenced by M\&A behavior based on different M\&A incentive through the regression model.

$$
\mathrm{ROA}=\alpha+\beta_{1} \mathrm{CRL}+\beta_{2} \mathrm{CRG}+\beta_{3} \mathrm{CRF}+\beta_{4} \mathrm{CRM}+\beta_{5} \mathrm{TBQ}+\beta_{6} \mathrm{ROE}+\varepsilon
$$

Among them $\alpha$ is a constant as a random error term.

\section{Empirical Results}

\subsection{Descriptive Statistics}

Table 2. Descriptive statistical analysis of main variables.

\begin{tabular}{|c|c|c|c|c|c|}
\hline & $\mathbf{N}$ & Minimum & Maximum & Mean Value & Standard Deviation \\
\hline Return on assets & 172 & -0.331165 & 0.789982 & 0.04371644 & 0.086242026 \\
\hline The ratio of the first shareholder's shares & 172 & 6.6932 & 75.7786 & 33.852414 & 14.7629971 \\
\hline The ratio of stated-owned shares & 172 & 0 & 77 & 4.79 & 14.069 \\
\hline The ratio of managerial ownership & 172 & 0.00000 & 71.05064 & 9.4270437 & 18.91639034 \\
\hline The ratio of circulation shares & 172 & 19.99548 & 100.00000 & 74.6512782 & 27.31483946 \\
\hline Tobin's Q & 172 & 0.943408 & 25.807278 & 2.45743483 & 2.454380054 \\
\hline Return on equity & 172 & -1.086183 & 0.930781 & 0.06411287 & 0.157300988 \\
\hline
\end{tabular}

Table 2 is the descriptive statistic for the main variables. Through the analysis of the data in the table, we can see that the range of values of return on assets and return on equity is small, the maximum and the minimum of the two peak gap is not big, and the standard deviation is maintained at a very small level. It explains that the distribution is concentrated. And explanatory variables, the ratio of the first shareholder's shares, the ratio of stated-owned shares, the ratio of managerial ownership, its difference between the minimum and maximum value is very large, and standard deviation value is also larger. It explains that the distribution is not concentrated and the discrete degree is large. For example, the minimum concentration of ownership is about $6.69 \%$, maximum value up to $75.78 \%$. The data shows the current enterprises' difference of distribution patterns and irrationality.

\subsection{Correlation Analysis}

The correlation analysis should be carried out prior to multiple regressions. The Pearson correlation analysis was carried out, as shown in Table 3. 
Table 3. The Pearson correlation analysis.

\begin{tabular}{|c|c|c|c|c|c|c|c|c|}
\hline & & $\begin{array}{l}\text { Return } \\
\text { on assets }\end{array}$ & $\begin{array}{l}\text { The ratio of the first } \\
\text { shareholder's shares }\end{array}$ & $\begin{array}{l}\text { The ratio of } \\
\text { stated-owned } \\
\text { shares }\end{array}$ & $\begin{array}{l}\text { The ratio of } \\
\text { managerial } \\
\text { ownership }\end{array}$ & $\begin{array}{l}\text { The ratio of } \\
\text { circulation } \\
\text { shares }\end{array}$ & $\begin{array}{l}\text { Tobin's } \\
\text { Q }\end{array}$ & $\begin{array}{l}\text { Return } \\
\text { on equity }\end{array}$ \\
\hline \multirow{3}{*}{ Return on assets } & $\begin{array}{l}\text { Pearson } \\
\text { correlation }\end{array}$ & 1 & 0.060 & 0.014 & $0.202^{* *}$ & $-0.251^{* *}$ & $0.311^{* *}$ & $0.871^{* *}$ \\
\hline & $\begin{array}{l}\text { Significance } \\
\text { (2-tailed) }\end{array}$ & & 0.436 & 0.856 & 0.008 & 0.001 & 0.000 & 0.000 \\
\hline & $\mathrm{N}$ & 172 & 172 & 172 & 172 & 172 & 172 & 172 \\
\hline \multirow{3}{*}{$\begin{array}{l}\text { The ratio of the } \\
\text { first shareholder's } \\
\text { shares }\end{array}$} & $\begin{array}{l}\text { Pearson } \\
\text { correlation }\end{array}$ & 0.060 & 1 & $0.222^{* *}$ & 0.003 & $-0.158^{*}$ & -0.110 & 0.048 \\
\hline & $\begin{array}{l}\text { Significance } \\
\text { (2-tailed) }\end{array}$ & 0.436 & & 0.003 & 0.965 & 0.038 & 0.149 & 0.531 \\
\hline & $\mathrm{N}$ & 172 & 172 & 172 & 172 & 172 & 172 & 172 \\
\hline \multirow{3}{*}{$\begin{array}{l}\text { The ratio of } \\
\text { stated-owned } \\
\text { shares }\end{array}$} & $\begin{array}{l}\text { Pearson } \\
\text { correlation }\end{array}$ & 0.014 & $0.222^{* *}$ & 1 & $-0.156^{*}$ & $-0.304^{* *}$ & -0.067 & 0.036 \\
\hline & $\begin{array}{l}\text { Significance } \\
\text { (2-tailed) }\end{array}$ & 0.856 & 0.003 & & 0.041 & 0.000 & 0.385 & 0.641 \\
\hline & $\mathrm{N}$ & 172 & 172 & 172 & 172 & 172 & 172 & 172 \\
\hline \multirow{3}{*}{$\begin{array}{l}\text { The ratio of } \\
\text { managerial } \\
\text { ownership }\end{array}$} & $\begin{array}{l}\text { Pearson } \\
\text { correlation }\end{array}$ & $0.202^{* *}$ & 0.003 & $-0.156^{*}$ & 1 & $-0.558^{* *}$ & -0.112 & 0.098 \\
\hline & $\begin{array}{l}\text { Significance } \\
\text { (2-tailed) }\end{array}$ & 0.008 & 0.965 & 0.041 & & 0.000 & 0.145 & 0.200 \\
\hline & $\mathrm{N}$ & 172 & 172 & 172 & 172 & 172 & 172 & 172 \\
\hline \multirow{3}{*}{$\begin{array}{l}\text { The ratio of } \\
\text { circulation shares }\end{array}$} & $\begin{array}{l}\text { Pearson } \\
\text { correlation }\end{array}$ & $-0.251^{* *}$ & $-0.158^{*}$ & $-0.304^{* *}$ & $-0.558^{* *}$ & 1 & $0.183^{*}$ & $-0.157^{*}$ \\
\hline & $\begin{array}{l}\text { Significance } \\
\text { (2-tailed) }\end{array}$ & 0.001 & 0.038 & 0.000 & 0.000 & & 0.016 & 0.040 \\
\hline & $\mathrm{N}$ & 172 & 172 & 172 & 172 & 172 & 172 & 172 \\
\hline \multirow{3}{*}{ Tobin's Q } & $\begin{array}{l}\text { Pearson } \\
\text { correlation }\end{array}$ & $0.311^{* *}$ & -0.110 & -0.067 & -0.112 & $0.183^{*}$ & 1 & $0.220^{* *}$ \\
\hline & $\begin{array}{l}\text { Significance } \\
\text { (2-tailed) }\end{array}$ & 0.000 & 0.149 & 0.385 & 0.145 & 0.016 & & 0.004 \\
\hline & $\mathrm{N}$ & 172 & 172 & 172 & 172 & 172 & 172 & 172 \\
\hline \multirow{3}{*}{ Return on equity } & $\begin{array}{l}\text { Pearson } \\
\text { correlation }\end{array}$ & $0.871^{* *}$ & 0.048 & 0.036 & 0.098 & $-0.157^{*}$ & $0.220^{* *}$ & 1 \\
\hline & $\begin{array}{l}\text { Significance } \\
\text { (2-tailed) }\end{array}$ & 0.000 & 0.531 & 0.641 & 0.200 & 0.040 & 0.004 & \\
\hline & $\mathrm{N}$ & 172 & 172 & 172 & 172 & 172 & 172 & 172 \\
\hline
\end{tabular}

**. Correlation is significant at the 0.01 level (2-tailed).

*. Correlation is significant at the 0.05 level (2-tailed).

From the correlation analysis of the table above, we can see that the return on assets and the ratio of managerial ownership, the ratio of circulation shares, Tobin's Q value and the return on equity at the .01 level (2-tailed) are significantly related.

\subsection{Regression Analysis}

Table 4 is a complex correlation coefficient table. The multiple correlations $\mathrm{R}$ are the coefficient to judge regression equation whether fits well or not. The larger the number is, the better the fitting degree is. In model 1 , the value of $R$ is 0.895 , and the $\mathrm{R}$ square is 0.801 , which indicates that the fitting degree is better. The trial rate $\mathrm{R}$ square is $31.8 \%$, which indicates it can pass the test in general. The $\mathrm{F}$ in table 5 is 110.378 , Sig. $=0.000<0.01$ both explains the regression equation is significant.

Table 4. The compound correlation coefficient table.

\begin{tabular}{lllll}
\hline Model & R & R Square & Adjusted R Square & Std0. Error of the Estimate \\
\hline 1 & $0.895^{\mathrm{a}}$ & 0.801 & 0.793 & 0.039209680 \\
\hline
\end{tabular}

a0. Predictors:(constant), Return on equity, The ratio of stated-owned shares, The ratio of managerial ownership, The ratio of the first shareholder's shares, Tobin's $\mathrm{Q}$, The ratio of circulation shares. 
Table 5. The analysis of variance table.

\begin{tabular}{llllll}
\hline Model & & Sum of squares & df & MS & F \\
\hline 1 & Regression & 10.018 & 6 & 0.170 & 1100.378 \\
& Residual & 0.254 & 165 & 0.002 & $0.000^{\text {a }}$ \\
& Total & 10.272 & 171 & & \\
\hline
\end{tabular}

a0. Predictors:(constant), Return on equity, The ratio of stated-owned shares, The ratio of managerial ownership, The ratio of the first shareholder's shares, Tobin's Q, The ratio of circulation shares.

b0. Dependent Variable: Return on assets

The table 6 was obtained by the regression analysis of the model.

Table 6. The regression analysis of the model.

\begin{tabular}{|c|c|c|c|c|c|c|}
\hline \multicolumn{2}{|c|}{ Model } & \multicolumn{2}{|c|}{ Unstandardized Coefficient } & \multirow{3}{*}{$\begin{array}{l}\text { Standardized Coefficient } \\
\text { Beta }\end{array}$} & \multirow{3}{*}{$\begin{array}{l}\mathbf{t} \\
10.469\end{array}$} & \multirow{3}{*}{$\begin{array}{l}\text { Sig. } \\
0.144\end{array}$} \\
\hline \multirow{6}{*}{1} & & $\mathrm{~B}$ & Std0. Error & & & \\
\hline & (constant) & 0.024 & 0.016 & & & \\
\hline & The ratio of the first shareholder's shares & 0.000 & 0.000 & 0.027 & 0.761 & 0.448 \\
\hline & The ratio of managerial ownership & 0.000 & 0.000 & 0.065 & 10.407 & 0.161 \\
\hline & The ratio of circulation shares & 0.000 & 0.000 & -0.125 & -20.568 & 0.011 \\
\hline & Tobin's Q & 0.006 & 0.001 & 0.164 & 40.454 & 0.000 \\
\hline
\end{tabular}

a0. Dependent Variable Return on assets.

We can find the fact by table 6 :

- Although there is a correlation relationship between ratios of No. 1 shareholder's shares, the ratio of managerial ownership and return on assets, it is not significant and violates the assumption one and the assumption three. Maybe this is on account of very few companies reducing the agency cost by executives holding shares. Low ratio of managerial ownership can not coordinate the conflicts of interests between the owner and the agent in the current market environment in China.

- The ratio of state-owned shares is negatively related to the return on assets and is significant at the level of $5 \%$. It explains that the higher the ratio of state-owned shares in the enterprise, the lower the return on assets, which reflects the reduction of the performance after Mathis and is consistent with the assumption two. The reason is that the ratio of state-owned shares in the enterprise is too high thus leads to the absence of the owner. If the power of agents becomes greater and effective supervision and management are insufficient, agents will be more likely to carry out M\&A based on the consideration of their own purpose, which will reduce the performance of enterprises.

- The ratio of circulation shares is negatively related to the return on assets and is significant at the level of $5 \%$. This is not consistent with the assumption four. After analyzing the reasons, we can find that the higher the ratio of the circulation shares will constrain the manager's M\&A behavior due to agency motivation. However, in the case of China's capitalist market is not sound, the ratio of circulation shares can not give full play to its role in the supervision of the manager. On the contrary, the higher ratio will lead to the decentralization of enterprise's power, which is not conducive to enterprises' M\&A behavior and results in reduction of performance of the enterprises.

- Tobin's Q value is significant related to the return on assets at $1 \%$ levels. This is consistent with the assumption five. Tobin's $Q$ value as a proxy variable for the management of enterprise managers, the higher the value is, the stronger the management ability of the managers is. The M\&A behavior led by it will increase the performance of the enterprises.

- The return on equity is positively related to the return on assets and is significant at the level of $1 \%$. This consistent with the assumption six. The return on equity is the main indicator of enterprise motivation. The higher the return on equity of the enterprise is before the M\&A, the more M\&A motivation likely to tend to be coordinated. It aims at carrying out M\&A from the perspective of realizing the maximization of the enterprise's value, which is beneficial to improve the performance of enterprise after M\&A.

\section{Conclusions and Suggestions}

\subsection{Conclusions}

Through a series of investigation, the article filters the major M\&A of listing corporation in 2011-2013 and verifies the assumption put forward by the above one by one, explaining the basic theory of M\&A and the relationship between motivation and performance. Then on the basis of summarizing the domestic and foreign literature and propose assumptions, the paper defined the relevant variables, and build the model, adopt the methods of descriptive statistics and scientific analysis, summarize the analysis result. The following conclusions are drawn: the ratio of state-owned shares and the ratio of circulation shares are negatively correlated with the performance of M\&A, which affects the performance of the enterprises after the M\&A. Tobin's Q 
value and the return on equity is significantly positive correlated with the return on assets, while the ratio of the first shareholder's shares and the ratio of managerial ownership in China's current capitalist market which has impact on M\&A is not significant.

\subsection{Suggestions}

According to the empirical research of private listed companies in China, this article puts forward the following suggestions in combination with the status quo of private enterprises in China:

- Private enterprises should update the concept of M\&A, develop and improve the company's strategic planning, carefully select the Target Corp based on the long-term perspectives to seek better and more stable merger. Strategic planning guides the development of enterprises, mergers and acquisitions are necessary if companies want long-term development. But if wanting to enhance the competitiveness of the company, expanding the scale of business through M\&A, private listed companies must proceed from reality, choose the appropriate M\&A market according to their own characteristics and development needs, and formulate the comprehensive strategy of M\&A.

- Integrate the enterprise from internal, and establish reasonable ownership structure. Under the modern enterprise system, perfect company system and reasonable ownership structure can guarantee the enterprise's own value as well as the shareholders' interests. Especially in the case of the large ratio of state-owned shares and legal person shares in our country, the enterprise internal integration is beneficial to solve the problem of the absence of the owner, reduce the acquisition event for agent motivation, which make the enterprise develop better.

- The government simplifies politics and transfers power to a lower level, clearing division of labor on the basis of improving their functions. The M\&A behavior of private enterprises in China can not get good results as scheduled, because the merger is not the pursuit of synergy effect, not to get better development, but for transfer the value under the system. Government departments should be aware of this problem that M\&A is a market behavior, for what the market can do, transferring power to the market and let the market rules to regulate enterprises' M\&A. Government departments should clear its own functions and play the supervisor's role, to develop and perfect the laws and regulations, supervise and protect enterprises' M\&A.

\section{References}

[1] Berkovitch, E. and M. P. Narayanan, Motives for Takeovers: An Empirical Investigation Journal of Financial and Quantitative Analysis. 1993 (28)

[2] Michael C. Jensen. Richaid S. Ruback. The Market for
Corporate Control: The Scientific Evidence. Journal of Financial Economics. 1983 (11)

[3] Jensen, M. C., Agency Costs and Free Cash Flow, Corporate Finance and Takeovers, American Economic Review Proceedings. 1986 (76)

[4] Keith D Brouthcrs. Paul van Hastcnburg. Joran vanden Ven. If Most Mergers Fail Why Are They So Popular? Long Range Planning, 1998 (31)

[5] Henri Servaes. Tobin's Q and the Gains from Takeovers, the Journal of Finance. 1991 (46)

[6] Yu Yulong, Chao Laichun. Research on the motivation of private enterprise merger and acquisition in China [J]. East China Economic Management. 2005 (09)

[7] Xia Xinping, Zou Zhaohui, Pan Hongbo. Empirical research on $\mathrm{M} \& \mathrm{~A}$ performance under different M\&A Motives [J]. Statistical observation. 2007 (229)

[8] Luo Wenlong. On private enterprise merger and acquisition [J]. Modern economic information. 2009 (19)

[9] Li Guoqiang, Li chu. The process, characteristics, types, reasons and policies of private enterprises in China [J]. Journal of Chongqing University of Technology. 2010 (06)

[10] Song Yingying, Huang Manli, Wang Huang. Analysis on the diversified M\&A of Chinese private enterprises based on the view of system $[\mathrm{J}]$. Science and technology management. 2010 (24)

[11] Zhu xiuhua. Research on the performance of the listing Corporation based on the different M\&A Motives. The full text database of Chinese outstanding master's degree thesis. 2012

[12] Feng Genfu, Wu Lingjiang. An empirical study on the M\&A performance of listing Corporation in China $[\mathrm{J}]$. Economic Research. 2001 (01)

[13] Zhang Xin. Whether mergers, acquisitions and reorganization can create value? The oretical and empirical research on Chinese stock market. Economic research. 2003 (6)

[14] Li Shanmin, Zhu Tao, Chen Yugang, Zeng Zhaozao, Wang Caiping. An empirical analysis of the combination of the acquiring company and the target company. Economic research. 2004 (6)

[15] Yu Li, Liu Ying. An empirical analysis of the M\&A performance of the listing Corporation in China $[\mathrm{J}]$. Contemporary economic science. 2004 (04)

[16] Li Zengquan. Hollowed out, and empirical evidence to support mergers and acquisitions from China listing Corporation. Economic research. 2005 (1)

[17] Lou Jin. Research on the performance of M\&A based on M\&A Motives. The full text database of Chinese outstanding master's degree thesis. 2006

[18] Zou Zhaohui. An empirical study of the influence of enterprise M\&A on M\&A performance. The full text database of Chinese outstanding master's degree thesis. 2006

[19] Zhao Hongying, Qi Xiaoyan, Li Jing, Hu Hanhui. An empirical study on the influence of M\&A behavior of private listing Corporation in China [J]. Journal of Central South University (Social Science Edition). 2008 (01) 
[20] Xi Xin, Chen Xin. An empirical study on the influence factors of M\&A performance of listing Corporation [J]. Industrial Technology. 2010 (9)

[21] Sheng Mingquan, Zhang Chunqiang. Research on the value effect of enterprise M\&A based on different M\&A types [J]. Business Economics and management. 2011 (9)
[22] Xu feng. Research on the M\&A of performance of Chinese listing corporation and the related influence factors based on the study on private listing corporation. The full text database of Chinese outstanding master's degree thesis. 2011

[23] Xu peng. Theoretical and empirical research on the motivation of enterprise merger and acquisition in China. The full text database of Chinese outstanding master's degree thesis. 2007 